\title{
TRAINING OF QUALIFIED SPECIALISTS IN THE PROCESS OF THEIR EDUCATION IN UNIVERSITY: THE ROLE OF THE PUBLIC-PRIVATE PARTNERSHIP
}

\author{
Talgat Uteubayev $^{1}$, Mariana Petrova ${ }^{2 *}$, Irena Lyubenova $^{3}$
}

\begin{abstract}
This article is devoted to the problem of forming qualified specialists in the labor market during the process of their education in university. This article presents the mechanisms of integration of education and business on the basis of a public-private partnership with the identification of strategic objectives, directions, and expected results of interaction between the educational institution and employers' enterprises in the training of qualified specialists. The expected results of the interaction between the subjects of the public-private partnership based on the results of the implementation of organizational and educational support for the personality of the student, teacher, employer and the state as a whole are revealed. A scheme for organizing a resource center for the interaction between an educational institution and employers' enterprises, as well as the effectiveness of its creation. The new mechanism for the sustainable development of the higher education system should solve the following strategic tasks: expansion of educational and research activities of universities and other organizations of the higher education system on the basis of the development of scientific schools and practice; interaction of fundamental scientific research and university vocational education; strengthening of the connection between the practice-oriented and research components of the university; the introduction of a competence approach that allows the linking of professional competencies that meet modern realities and market requirements in order to achieve the goald of higher education; increasing the level of preparation of competitive human resources in demand for students of universities in the domestic labor market.
\end{abstract}

JEL Classification Numbers: I20, M10, M12, M16, L20; DOI: http://dx.doi.org/10.12955/cbup.v6.1203

Keywords: human resources, qualified specialist, business, university, education, public-private partnership

\section{Introduction}

The formation of competences of future specialists should assume an educational environment that is able to provide a combination of applied and fundamental training of future specialists, a mastery of professional activity, vocational training and education, the ability to independently see problems, design knowledge, find solutions to problems.

In modern conditions, the content of pedagogical activity in the higher education insitutes of Kazakhstan is fundamentally changing. Priority is given to such professional and pedagogical competencies such as the ability to participate in the work of program-target teams in the formation of: the graduate's competence model; a database of modern valuation tools for the purpose of conducting intermediate, final controls on the knowledge of students; substantive and logical connections of modules, disciplines, practices, research work that are part of the specialty education program; support of research activities and independent work of students, etc. (Bishimbaev, 2014).

In modern conditions, quality management of education is impossible without the interested participation of the main subjects of the educational process, including students. Accordingly, there is a need to change the ideology of quality management in education. (Kurmanov et al., 2015; Nenkov et al., 2017B).

In Kazakhstan, the modernization of the higher education system takes place in a competitive environment. In the conditions of modernization of the economy, the priority goal of any country's higher education institutions should be the production of highly competitive specialists who possess a wide range of professional qualities, such as: adaptation in social and professional spheres; the ability to make independent decisions; stress resistance; the ability to work in a team, etc.

In modern conditions, serious employers willingly cooperate with advanced universities and look forward to highly competitive specialists, taking part in joint scientific and educational projects (Nenkov et al., 2017A; Yeleussov, 2015: Kurmanov et al., 2016A). Thus, one of the ways to improve the quality of human resources should be the creation of a system of public-private partnership of employers with educational institutions that will ensure the further development of higher education and the overall economy of the country.

\footnotetext{
${ }^{1}$ D. A. Tsenov Academy of Economics, Svishtov, Bulgaria, talgat4001@ mail.ru

2 "St.Cyril and St.Methodius" University of VelikoTarnovo, Bulgaria, m.petrova@ts.uni-vt.bg, *Corresponding author

${ }^{3}$ D. A. Tsenov Academy of Economics, Svishtov, Bulgaria, i.emilova@ uni-svishtov.bg
} 


\section{Model of interaction between an educational institution and employers' enterprises in the training of qualified specialists}

The development of an organizational model for the interaction of the educational institution with employers' enterprises in the training of qualified specialists in Kazakhstan at all levels requires an updated regulatory and legal framework for the implementation of organizational and educational support for the training of students for the real sector of the economy (Uteubayev, 2016; Kurmanov et al., 2016B).

The interest of employers and professional communities to participate in the interaction with the education system is, first of all, in the benefits (results) that they will receive from the implementation of the mechanism of the public-private partnership an educational institution with employer enterprises in the training of qualified specialists (Table 1).

Table 1: Public private partnership (PPP) entities and expected results of interaction based on the results of the implementation of organizational and educational support

\begin{tabular}{|c|c|}
\hline Subject of partnership & Expected results of interaction \\
\hline Personality student & $\begin{array}{l}\text { - a reduction in personal spending on retraining; } \\
\text { the success of the social and professional adaptation of the future } \\
\text { specialist to production; } \\
\text { professionally self-determined personality improves general and } \\
\text { professional competences, deliberately masters the future profession, } \\
\text { which provides a real opportunity for successful employment. }\end{array}$ \\
\hline Teachers & $\begin{array}{l}\text { - } \quad \text { a reduction in personal spending on retraining; } \\
\text { the development of teachers of the education system is receptive to the } \\
\text { needs of employers; } \\
\text { professional development of teachers of the education system through } \\
\text { the production of training in partner organizations, the exchange of } \\
\text { experience with qualified professionals. }\end{array}$ \\
\hline $\begin{array}{c}\text { Employer, professional } \\
\text { community }\end{array}$ & $\begin{array}{l}\text { - the lack of the need for the functioning and development of training } \\
\text { departments at the enterprises themselves, as well as the cost of money } \\
\text { for their operation; } \\
\text { professionally motivated and self-determined specialists with the } \\
\text { necessary professional competencies and able to adapt to changing } \\
\text { conditions and technologies, provide: labor productivity growth, } \\
\text { increase in production efficiency, profit growth, increase in sales } \\
\text { volumes from the activities of professionals, and lower production costs. }\end{array}$ \\
\hline The state & $\begin{array}{l}\text { - financial security and security of citizens; } \\
\text { - an increase in the number of young professionals who are employed and, } \\
\text { as a result, a decrease in social tension; } \\
\text { - reduction of costs for retraining. }\end{array}$ \\
\hline
\end{tabular}

Source - compiled by the authors

The management of the mechanism of interaction between the educational institution and employers' enterprises can be visualized in the form of a resource center scheme (Figure 1) and schemes for managing the public-private partnership of the educational institution with employers' enterprises (Figure 2).

Thus, the main areas of cooperation within the framework of the public-private partnership program of the educational institution with employers are: the conclusion of long-term contracts for targeted training, the internship of teachers on the equipment of enterprises, the establishment of a training ground at partner enterprises, the organization of continuing education, the organization of training and retraining of personnel (mastering new competencies for a new type of activity), etc.

Forms of public-private partnership of an educational institution with employers are small innovative enterprises, contracts and endowment funds (Uteubayev \& Petrova, 2017), among which life insurance can play a very important role (Pukala\&Adamisin, 2015).

But to achieve it is necessary to increase funding, for example in general, for EU (28 countries) R\&D expenditure share in GDP increased by 16,67 \% from 2005 and in 2015. (Labunska et al., 2017). 


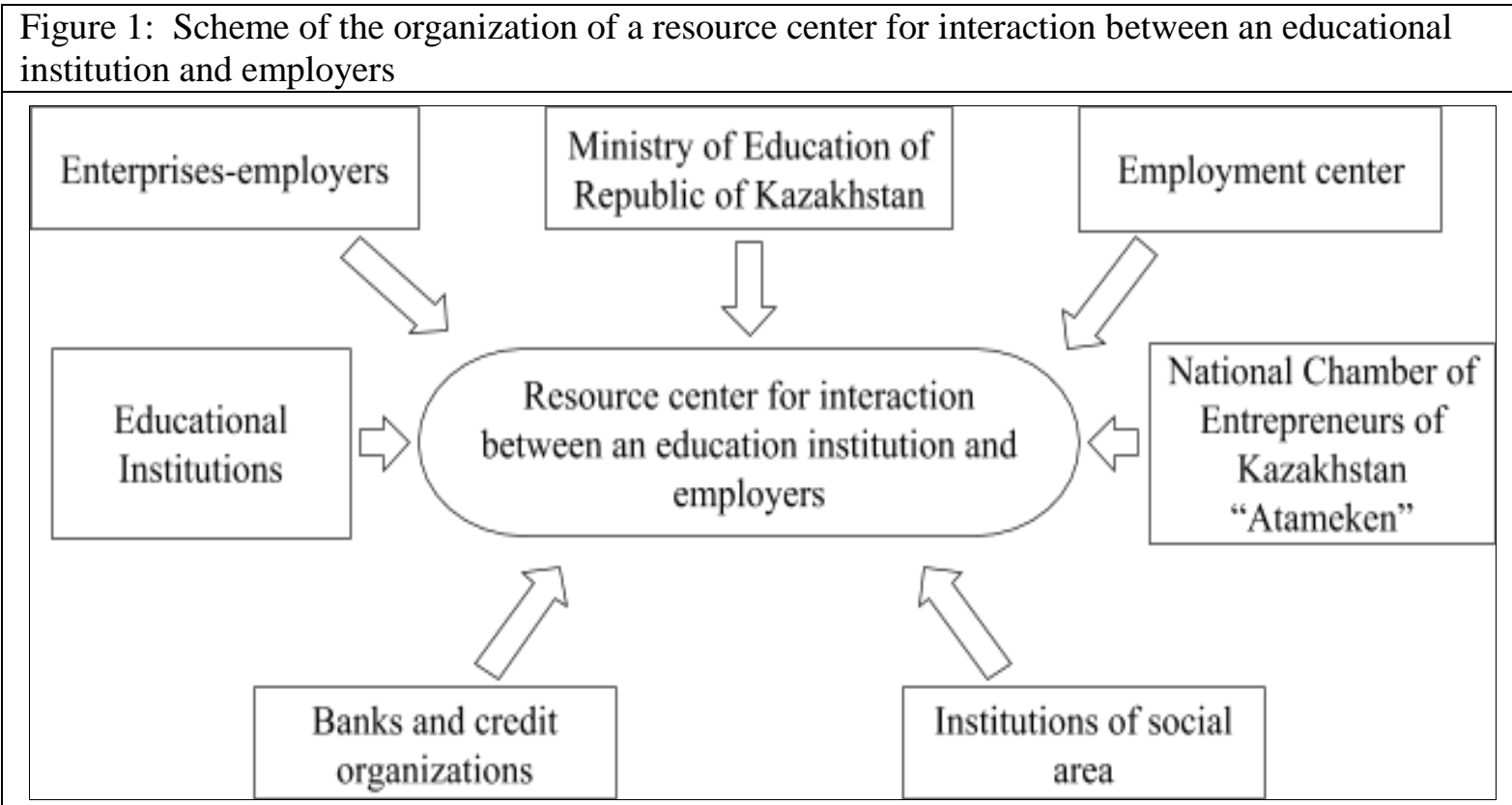

Source - compiled by the authors

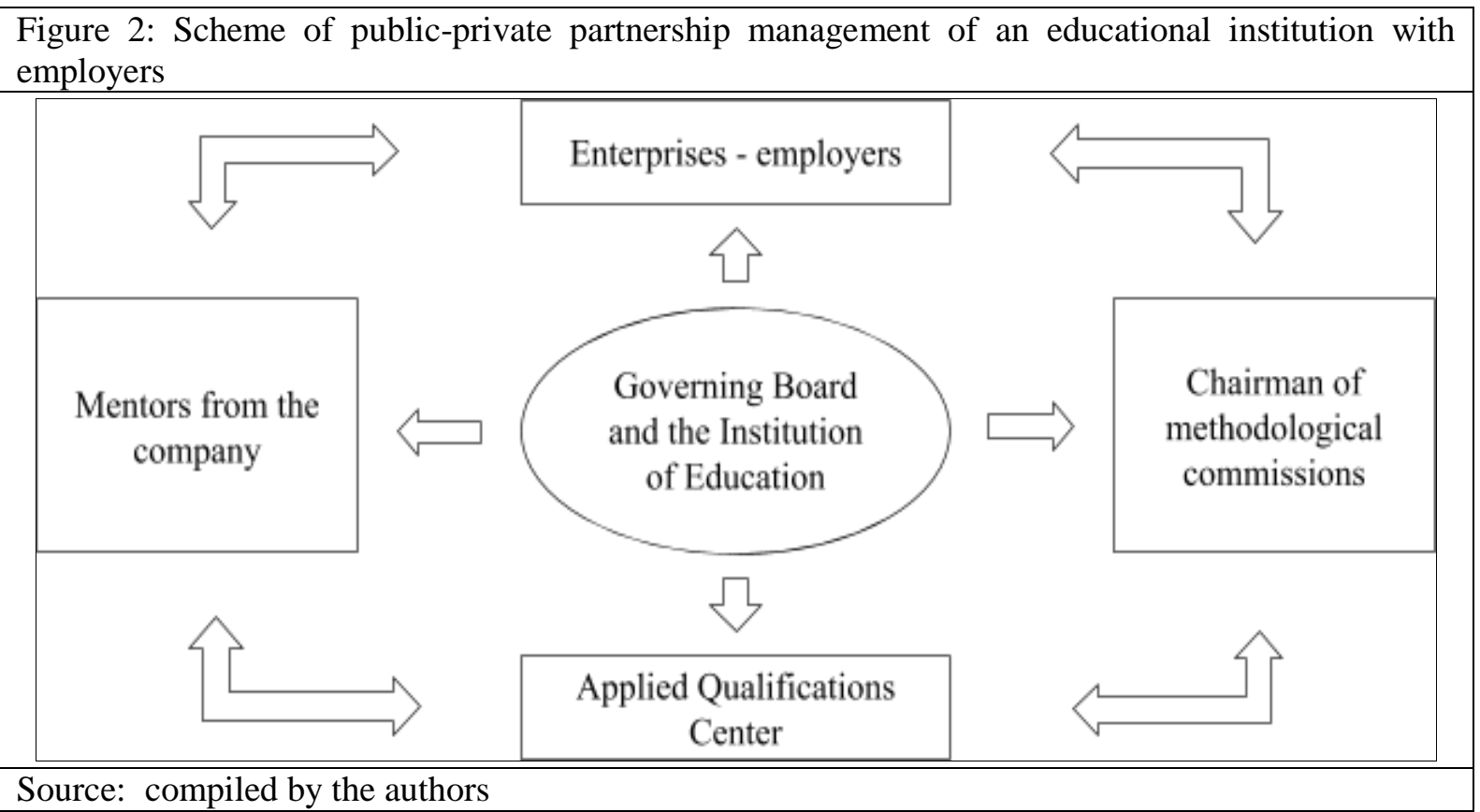

The forms of cooperation can vary depending on the urgent needs of partner enterprises and an educational institution:

- workplaces for the passage of practices;

- participation in the development of components of educational programs, control and evaluation materials;

- $\quad$ articipation in the final state certification of trainees;

- conducting an external expert evaluation of teaching materials;

- internships of teaching staff;

- employment of graduates;

- attraction of specialists of enterprises as managers of final qualification works and their reviewing;

- familiarization of teachers and students with new models of technology and technology; 
- $\quad$ target set (conclusion of tripartite agreements);

- nominal scholarships, retraining of enterprise employees in the education system;

- participation in strengthening the educational and material base;

- participation in joint career-oriented activities, etc.

Efficiency of creating a resource center for interaction between an educational institution and employers

A resource center acts as a coordinator of interactions of all interested professional educational institutions of different levels, enterprises of a particular branch of the economy, state and public authorities. A resource center is the center for the development of interaction between educational institutes and business institutions, and provides methodological, informational, organizational and marketing support for modern educational programs in accordance with the requirements of the real economy and the needs of the population.

A resource center for the interaction between the educational institutions and employers is an institutional structure that is built on the principles of a multi-faceted mutual complementation by participants in each other and functions with the help of the Governing Council in the establishment of education, which ensures the solution of the whole set of issues of the educational process: the improvement of the qualifications of all participants in the interaction within the framework of the public-private mechanism.

The effectiveness of creating a resource center is manifested in the following:

- in pedagogical expediency;

- the social component;

- in economic efficiency.

Pedagogical expediency of the realization of the interaction of the educational establishment with the enterprises-employers is shown:

0 in the continuous updating of the content of education;

0 in the integration of educational and methodological materials;

$\circ$ in the co-ordination of training programs and plans;

$\circ$ in supporting the foundations of a unified educational space in the field of secondary and higher vocational education.

The social significance of the interaction between an educational institution and employers' enterprises is manifested:

$\circ$ in ensuring the continuity and accessibility of vocational education;

- in achieving the variability of professional educational programs and plans;

$\circ$ in strengthening the positions of the resource center subjects through the implementation of educational programs in demand by the market;

$\circ$ in providing a full range of training and education services, taking into account the real needs of the partners of the resource center.

The economic efficiency of the creation and operation of a resource center for interaction between an educational institution and employers' enterprises is manifested:

$\circ$ in optimizing the resources of all participants in such interaction (redistribution and cooperation of resources in order to more fully return them);

- the availability of a variety of professional programs available to participants in the interaction;

- in savings of employers' funds and public funds;

$\circ$ in achieving the continuity and effectiveness of professional higher education.

\section{Conclusions}

The new mechanism for the sustainable development of the higher education system, taking into account the above directions, in our opinion, should solve the following strategic tasks: expansion of educational and research activities of universities and other organizations of the higher education system on the basis of the development of scientific schools and practice; interaction of fundamental scientific research and university vocational education; strengthening of the connection between the practice-oriented and research components of the university; the introduction of a competence 
approach that allows the linking of professional competencies that meet modern realities and market requirements in order to achieve the goald of higher education; increasing the level of preparation of competitive human resources in demand for students of universities in the domestic labor market.

\section{Acknowledgements}

The research is financed by Project № FSD - 31-813/ 28.06.2016 „Developing a web portal of the electronic periodicals of "St. Cyril and St. Methodius" University of Veliko Tarnovo, Bulgaria.

\section{References}

Bishimbaev V. (2014). The success of innovation economy is determined by cadres. Kazakhstan's truth. 2014. - 11 July.

Ministry of Education and Science of the Republic of Kazakhstan, National Center for Educational Statistics and Evaluation. Statistical collection. - Astana, 2016.

Kurmanov, N., Yeleussov, A., Aliyev, U., \& Tolysbayev, B. (2015). Developing effective educational strategies in Kazakhstan. Mediterranean Journal of Social Sciences, 6(5), 54.

Kurmanov, N. A., Mutaliyeva, L. M., \& Uteubayev, T. B. (2016A). Human Capital and Human Resources: problems of their effective use.// Bulletin of the University journal of Karaganda State University named after academician E. A. Buketov, ECONOMY Series, №3(83). - C. 28-33

Kurmanov, N., Tolysbayev, B., Aibossynova, D., \& Parmanov, N. (2016B). Innovative activity of small and medium-sized enterprises in Kazakhstan and factors of its development. Економічний часопис-XXI, (158), 57-61.

Labunska Sv., Petrova M., Prokopishyna O. (2017). Asset and cost management for innovation activity. Economic Annals XXI. VOLUME 165, ISSUE 5-6, Pages: 13-18. DOI: https://doi.org/10.21003/ea.V165-03

Nenkov, N; Dyachenko, Y; Petrova, M; Bondarenko, G; Pustovit, V. (2017B). Intelligent and Cognitive Technologies in Education of International Economic Relations Students and Human Resource Development in Enterprises: Methodology in Language. European Journal of Sustainable Development. Publisher: European Center of Sustainable Development, Rome, Italy, Vol 6, No.4, , pp.353-360, DOI: 10.14207/ejsd.2017.v6.n4.p353

Nenkov, N; Tasinov, T; Petrova, M. (2017A). Software system for document management at the Faculty to University, 4th International Multidisciplinary Scientific Conference on Social Sciences and Arts, SGEM 2017. Conference Proceedings, VOL V Science and Society. Book 3, Education \& Educational Research, Pages: 457-464, DOI:10.5593/SGEMSOCIAL 2017/35/S13.060

Nenkov, N., Sushchenko, O., Dyachenko Y. (2017C) Role of chief information officer within the system of human resource development in the service organizations (tourism) // Economic Annals-XXI. - Issue 5-6. - Vol. 165. - P. 97-103.

Pukała R., Adamisin P. (2015), Unit-linked life insurances where the investment risk is borne by the policy holder as an element of shaping household savings portfolios in Poland after the accession to the European Union, European Financial Systems 2015 of the 12-th International Scientific Conference, Masaryk Faculty of Economic and Administration Department and Institute for Financial Market, June 18-19, 2015, Brno, Czech Republic, pp. 458-465.

Uteubayev, T. (2016). Comparative Analysis of Human Development in Kazakhstan and other Eurasian Economic Union Countries. International Journal of Economics and Financial Issues, Turkey, 2016. - Vol. 6, No. 4. - pp. 1419-1423

Uteubayev, T., \& Petrova, M. (2017). The development of human potential in Kazakhstan'S innovation economy. Business Management, issue 4, Tsenov Academic Publishing House, Svishtov, 2017, pp.75-89

Yeleussov, A., Kurmanov, N., \& Tolysbayev, B. (2015). Education quality assurance strategy in Kazakhstan. Actual Problems of Economics (2), 142-150. 